\title{
Radon and its decay product activities in the magmatic area of the Karkonosze Granite and the adjacent volcano-sedimentary Intrasudetic Basin
}

\author{
Andrzej Tomasz Solecki, Radoslaw Puchala and Dagmara Tchorz \\ Institute of Geological Sciences Wrockaw Univeristy, Wrockaw, Poland
}

\begin{abstract}
In the magmatic area of Sudetes covering the Karkonosze granite and adjacent volcano-sedimentary Intrasudetic Basin a study of atmospheric radon activity was performed by means of SSNTD Kodak LR-115. The study was completed by gamma spectrometric survey of eU and eTh determined by gamma activity of radon decay products ${ }^{214} \mathrm{Bi}$ and ${ }^{208} \mathrm{Tl}$ respectively. In the case of the western part of the Karkonosze granite area the radon decay products activity in the granitic basement was found to be as high as $343 \mathrm{~Bq} / \mathrm{kg}$ for ${ }^{214} \mathrm{Bi}$ and $496 \mathrm{~Bq} / \mathrm{kg}$ for ${ }^{208} \mathrm{Tl}$ respectively. Atmospheric radon content measured by means of Kodak LR115 track detector at the height of $1.5 \mathrm{~m}$ was found as high as $70 \mathrm{~Bq} / \mathrm{m}^{3}$ in the regions, where no mining activities took place. However in the eastern part of the granitic massif in the proximity of abandoned uranium mine atmospheric radon content was found to be $6000 \mathrm{~Bq} / \mathrm{m}^{3}$. In the case of sedimentary basin where sedimentary sequence of Carboniferous rocks has been penetrated by younger gases and fluids of volcanic origin uranium mineralization developed. The region known from its $\mathrm{CO}_{2}$ outburst during coal mining activity is characterized by good ventilation of the uranium enriched geological basement resulting in increased atmospheric radon activity being in average $72 \mathrm{~Bq} / \mathrm{m}^{3}$. In the vicinity of coal mine tailing an increase up to $125 \mathrm{~Bq} / \mathrm{m}^{3}$ can be observed. Seasonal variations of atmospheric radon content are influenced in agricultural areas by cyclic cultivation works (plough) on soils of increased uranium content and in the case of post-industrial brownfields varying rates of radon exhalation from tailings due to different meteorological conditions.
\end{abstract}

Key words radon - uranium - Sudetes - mining

\section{Introduction}

Average radon activity in Poland published by Central Laboratory for Radiological Protection is $4.4 \mathrm{~Bq} / \mathrm{m}^{3}$ (Jagielak et al., 1992). In the case of the whole area of Poland the fact of pre-

Mailng address: Dr. Andrzej Tomasz Solecki, Institute of Geological Sciences, Wroclaw University, pl. M. Borna 9, 50204 Wroclaw, Poland; e-mail: asol@ing.uni.wroc.pl dominance of Atlantic circulation on the windy Polish Lowlands must be taken into account. Low radon concentration in oceanic crust and waters strongly influences atmospheric radon concentration in the coastal areas. It results in such a low values as $0.4-1 \mathrm{~Bq} / \mathrm{m}^{3}$ in the case of Alaska and Hawaii (Gessel, 1983). In the latter, case superposition of altitude and marine influence results in $0.02-0.7 \mathrm{~Bq} / \mathrm{m}^{3}$ observed at the top of the Mauna Loa (3400 m a.s.1.) (Whittlestone et al., 1992).

Results of observations in SW Poland $30 \mathrm{~km}$ north of the uraniferous province of the Sudetes Mts. are 3.4 to $11.9 \mathrm{~Bq} / \mathrm{m}^{3}$ (Muras and Olszews- 
ki, 1993) and in close proximity to the Sudetes Mts. are $21 \mathrm{~Bq} / \mathrm{m}^{3}$ (Ochmann, 2003). Both values are lower than that of the uranium enriched arid Colorado Plateau where atmospheric radon activity is of order $27.8 \mathrm{~Bq} / \mathrm{m}^{3}$ (Gessel, 1983). The purpose of this work was to check radon atmospheric activities inside the Sudetes Mts. in uranium enriched areas.

\section{Area under investigation}

Radon and radon decay product measurements were performed in the area of the Sudety Mountains Variscan orogen forming the NE margin of the Bohemian Massif (fig. 1). In the highest part of the Sudetes the Karkonosze Massif of rapakivi type granite occurs. It originated at the end of Paleozoic (330-330 Myr) at the collisional continental margin (Mierzejewski, 1993). Uranium and thorium content of the Karkonosze Granite reaches its maximum value of 62 and 67 ppm respectively (Jeliński, 1965) making it the most radioactive area of the region. Uranium deposits have been exploited in its eastern contact zone with the metamorphic cover.

Simultaneously with granite intrusion the Lower Carboniferous Intrasudetic Basin developed. Clastic sediments with coal seams have been deposited there. Intensive volcanic activity of the Upper Carboniferous-Lower Permian age resulted in hydrothermal mineralization of some parts of coal seams and clastic sediments. Uranium mineralization of economic grade is known only from clastic sediments, although locally uranium content as high as 1000 ppm was also found in coal seams.

\section{Methods}

\subsection{Gamma spectrometric mapping}

Measurements of the bedrock radon decay products activity were performed using Exploranium GR-320 gamma radiation spectrometer with the standard NaI (Tl) GPX-21A detector of $0.35 \mathrm{~L}$ volume. The producer using traceable test pads performed calibration of the detector. According to producers manual impulses sup- plied by the detector probe were classified using channels 70-204 of the 256 channels of the spectrometer covering the energy window 850$2810 \mathrm{keV}$.

Three bands (Regions of Interests ROI) corresponding to energy windows of radionuclides peaks ${ }^{40} \mathrm{~K},{ }^{214} \mathrm{Bi}$ and ${ }^{208} \mathrm{Tl}$ were set up (table I).

The problem of stabilization of energy windows of channels was solved by means of continuous measurement of cesium $662 \mathrm{keV}$ photons from internal source in the band $\mathrm{RO} / 1$ covering channels 51-60 (600-730 keV). The gain parameter responsible for fitting channels to energy windows was continuously updated using least-squares fit of a Gaussian cesium peak shape every time the 5000 level of Cs counts was exceeded. This ensured that the system gain was always correct and selected channels corresponded to the desired energy windows.

Measured activities of radon and thoron decay products were recalculated into uranium and thorium concentrations (in ppm) assuming existence of equilibrium in uranium and thorium decay series, what is a common practice in this kind of measurements marked by eU and eTh notation instead of $U$ and Th. For each measurement the detector was deployed in the field using geometry as close as possible to $2 \prod$. Sampling time ranged from 15 to $30 \mathrm{~min}$ depending on local radionuclides content to reach statistically significant counts in all ROI's. Ambient temperature during measurements was in the range 5 to $25^{\circ} \mathrm{C}$.

\subsection{Radon activity measurements}

Radon activities were measured by means of the Kodak LR115 Solid-State Nuclear Track Detectors (SSNTD). Review of this method is given by Khan and Qureshi (1994). Alpha tracks in the cellulose trinitrate layer of KODAK LR115 were etched in hot $\mathrm{Na}(\mathrm{OH})$ and counted at the optical magnification of $100 \mathrm{x}$ Optiphot 2-Pol Nikon microscope.

Detectors were exposed at $1.5 \mathrm{~m}$ above ground level for 3-month periods. Calibration model and coefficients described by Srivastava et al. (1995) was applied. 


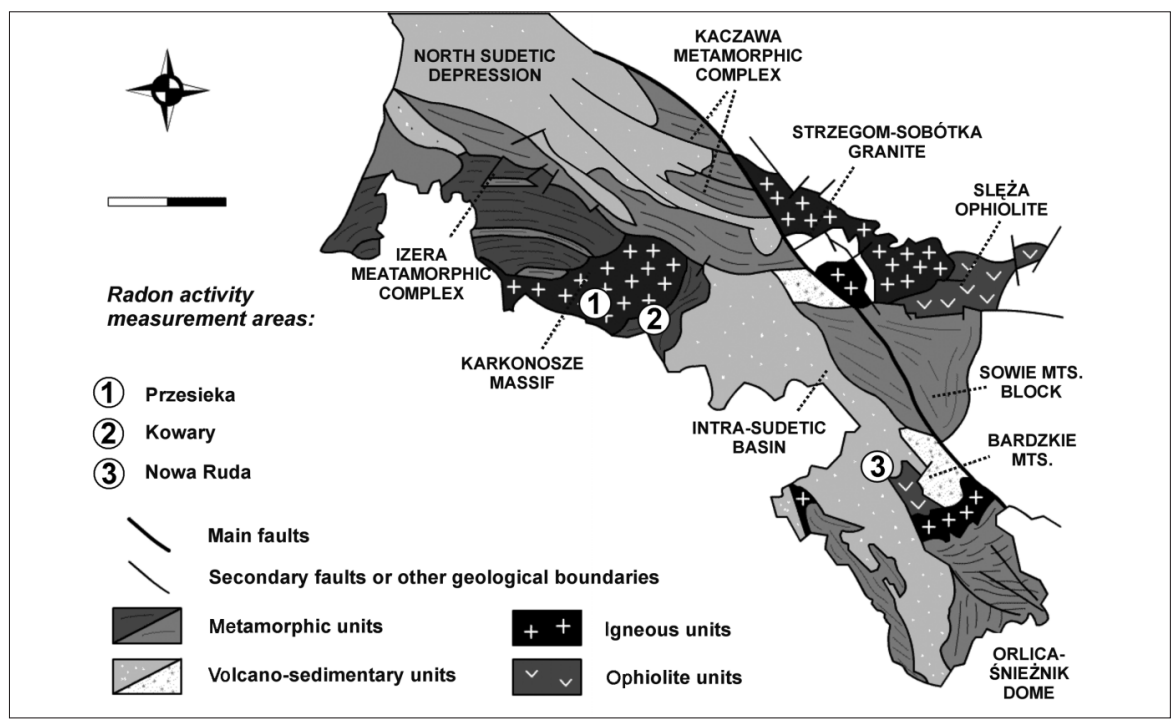

Fig. 1. Localization of atmospheric radon activity measurements in the Sudetes on the background of regional geology.

Table I. Gamma ray spectrometer GR-320 energy windows characteristics.

\begin{tabular}{ccccc}
\hline \hline Band & Radionuclide peak & Channels & Energy window (keV) & Sensitivity \\
\hline $\mathrm{RO} / 2$ & ${ }^{40} \mathrm{~K} 40460 \mathrm{keV}$ & $109-122$ & $1370-1570$ & $0.661 \mathrm{cps} / \%$ \\
$\mathrm{RO} / 3$ & ${ }^{214} \mathrm{Bi} 1760 \mathrm{keV}$ & $129-142$ & $1660-1860$ & $0.067 \mathrm{cps} / \mathrm{ppm}$ \\
$\mathrm{RO} / 4$ & ${ }^{214} \mathrm{Tl} 2620 \mathrm{keV}$ & $179-204$ & $2410-2810$ & $0.025 \mathrm{cps} / \mathrm{ppm}$ \\
\hline
\end{tabular}

\section{Results}

\subsection{Przesieka area}

Przesieka area (fig. 2a) is located in the central part of the Karkonosze Mts. National Park, where no visible traces of mining activity exist. Rock basement is composed here of two types of Karkonosze granite. Medium grained granite of slightly higher uranium content (6-12 ppm) occurs on the top of the hills, while porphyrytic granite of lower uranium content (3-6 ppm) forms the lower parts of the slopes (fig. 2b).

Uranium and thorium content of the bedrock varies here in a broad range $2-50 \mathrm{ppm}$ for urani- um and 3.1-92 ppm for thorium (figs. 3 and 4; table II).

Due to erosion and fluvial transport, more radioactive material derived from the top of the hills can be detected even in the lower parts of valleys. Emanation from accumulated material results in local atmospheric radon activity anomalies $70 \mathrm{~Bq} / \mathrm{m}^{3}$ distinctly higher than the regional background of $10 \mathrm{~Bq} / \mathrm{m}^{3}$.

\subsection{Kowary area}

In the case of Kowary area the main local source of radon is an abandoned uranium mine gallery used in the seventies of the XX century as 

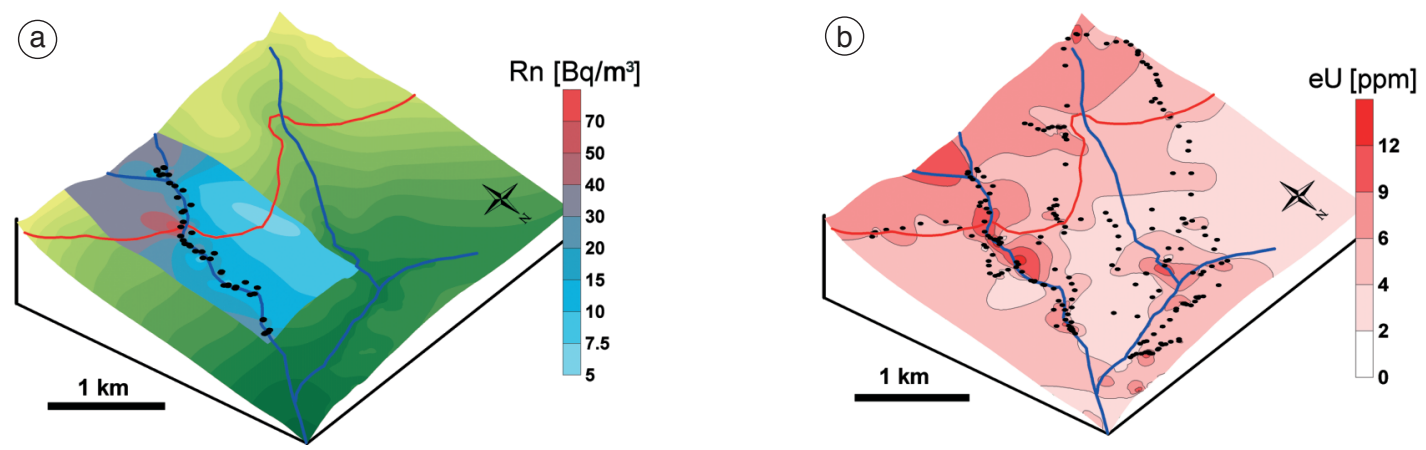

Fig. 2a,b. a) Atmospheric radon activity in the Przesieka area (red line separates outcrops of two types of granites, black dots - measurement points). b) Bedrock uranium (eU) content of the Przesieka area (red line separates outcrops of two types of granites, black dots - measurement points).

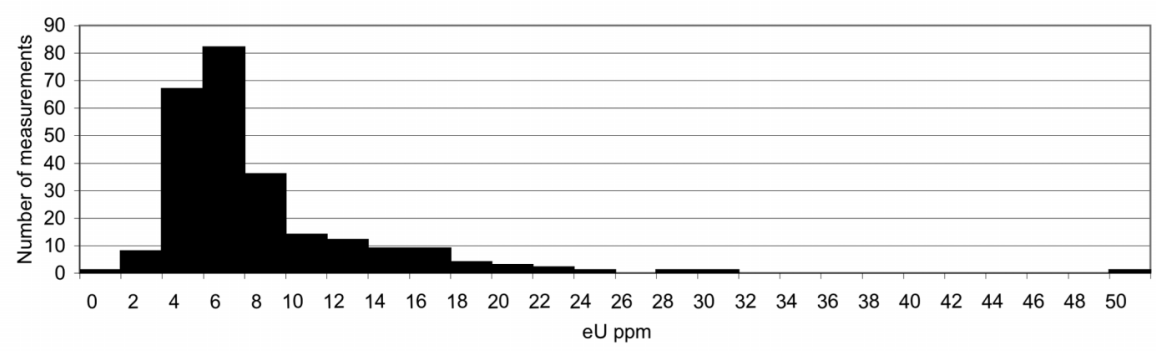

Fig. 3. Distribution of bedrock uranium (eU) content in the Przesieka area.

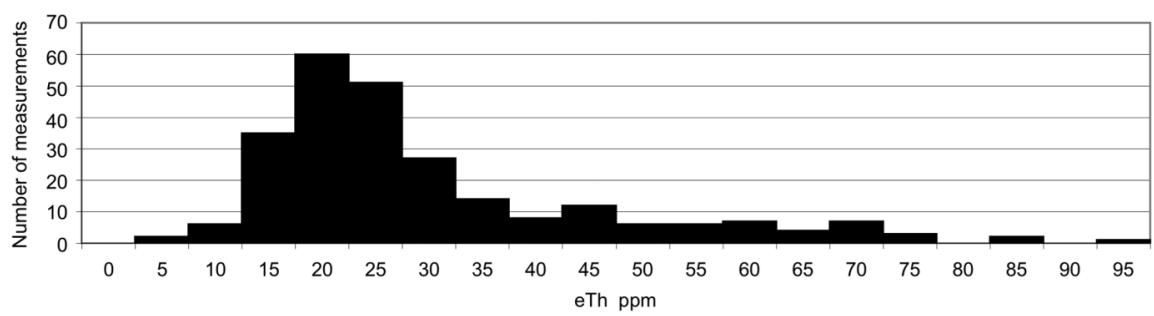

Fig. 4. Distribution of bedrock thorium (eTh) content in the Przesieka area.

radon inhalatorium (Banaś et al., 1976). Strong anomaly exceeding $4000 \mathrm{~Bq} / \mathrm{m}^{3}$ (fig. 5a) can be traced down the Jedlica Valley below the gallery entrance. The geological basement of the area is composed of metamorphic rocks partly covered by tailings of uranium content locally exceeding the value of $200 \mathrm{ppm}$ (fig. 5b.).

\subsection{Nowa Ruda area}

Nowa Ruda area is the country of gentle hills with poorly ventilated valleys. Permocarboniferous sediments of the Intrasudetic Basin discordantly contact with the pre-Variscan basement composed of the Sowie Mts. Block 
Table II. Summary of eU and eTh bedrock content in the Przesieka area.

\begin{tabular}{cccc}
\hline \hline & Min & Mean & Max \\
\hline $\mathrm{eU} \mathrm{ppm}$ & 2 & 6.73 & 50 \\
${ }^{214} \mathrm{Bi} \mathrm{Bq} / \mathrm{kg}$ & 25 & 83.7 & 621 \\
$\mathrm{eTh} \mathrm{ppm}$ & 3.1 & 27.4 & 92 \\
${ }^{208} \mathrm{Tl} \mathrm{Bq} / \mathrm{kg}$ & 12.7 & 112.4 & 377.6 \\
\hline
\end{tabular}

gneisses and gabbro diabases of the Nowa-Ruda Slupiec Massif (fig. 6). In the Carboniferous part of the profile numerous coal seams have been exploited in the past resulting in huge tailings of mined barren material and good ventilation of geological basement due to existence of numerous abandoned coal mines. A sedimentary sequence of Carboniferous rocks has been penetrated by younger gases and fluids of vol-

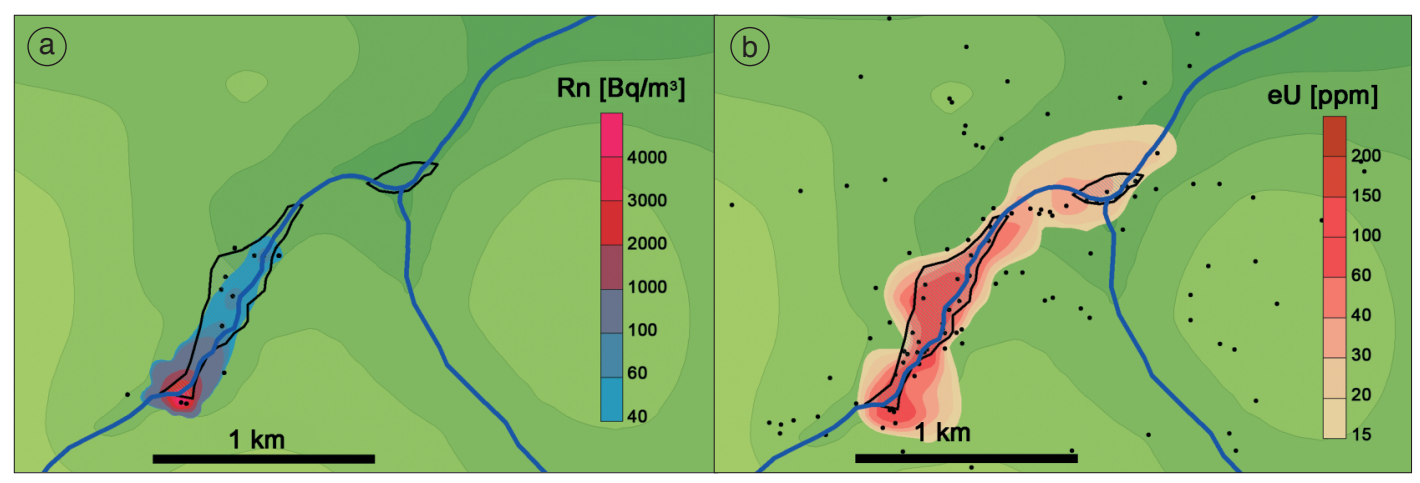

Fig. 5a,b. a) Atmospheric radon activity in the Jedlica Valley (black line - tailing boundary, black dots - measurement points). b) Uranium (eU) content of Jedlica Valley bedrock including tailing material (black line - tailing boundary, black dots - measurement points).

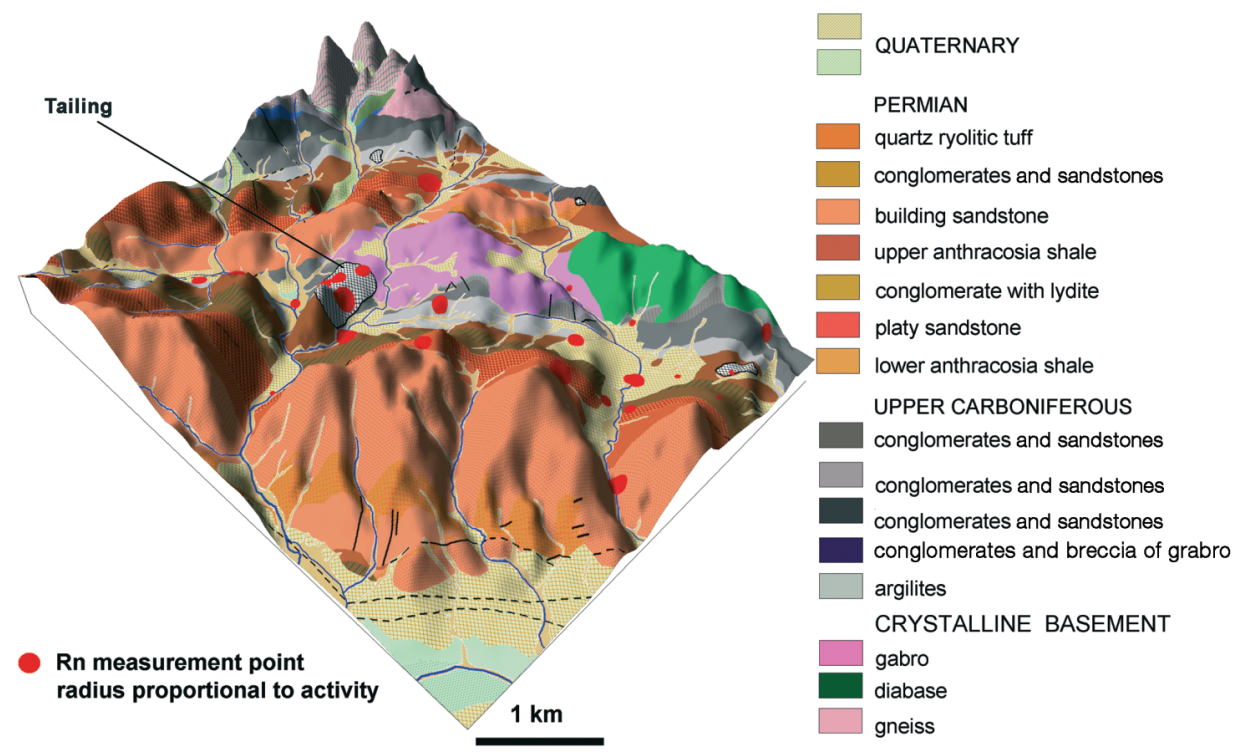

Fig. 6. Localization of radon measurement points on the geological background of the Nowa Ruda area. 
Table III. Bedrock uranium content and atmospheric radon activity in the Nowa Ruda area.

\begin{tabular}{cccccc}
\hline \hline & \multicolumn{4}{c}{ Rn in air $\left(\mathrm{Bq} / \mathrm{m}^{3}\right)$} & $\mathrm{eU}$ ppm \\
& $\begin{array}{c}\text { Autumn } \\
10-12 / 2004\end{array}$ & $\begin{array}{c}\text { Winter } \\
01-03 / 2005\end{array}$ & $\begin{array}{c}\text { Spring } \\
04-06 / 2005\end{array}$ & $\begin{array}{c}\text { Summer } \\
07-09 / 2005\end{array}$ & \\
\hline Regional mean & $71 \pm 2$ & $32 \pm 2$ & $86 \pm 2$ & $98 \pm 1$ & $2.4 \pm 0.25$ \\
Tailing area & 94 & 41 & 111 & 125 & 5.6 \\
\hline
\end{tabular}

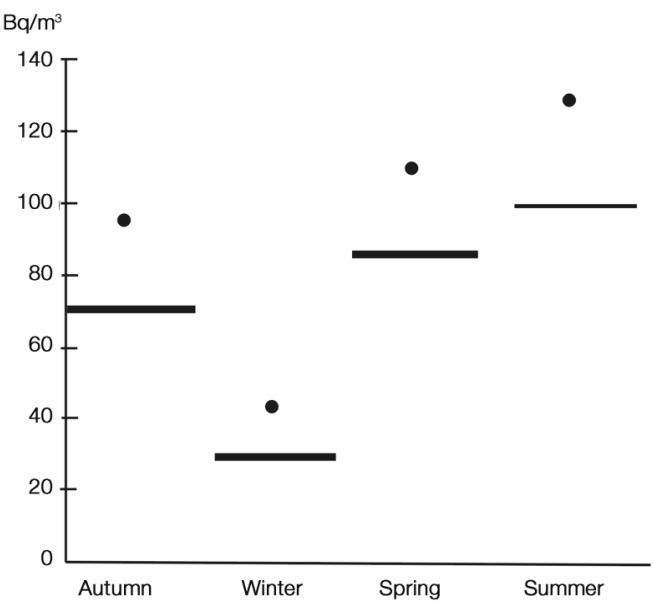

Fig. 7. Seasonal variation of atmospheric radon activity in the Nowa Ruda area. Black square - regional value (thickness of squares equal to standard error range); black dots - results for tailing area.

canic origin. The region is known from its $\mathrm{CO}_{2}$ outburst during mining activity being so intensive that local community around shafts was in danger. Regional bedrock uranium content in this area is $2.4 \mathrm{ppm}$ while tailing material is slightly more uraniferous $-5.6 \mathrm{ppm}$ (table III). Uranium mineralization of economic grade exists in some parts of the Walchia shale profile.

Atmospheric radon activity measurements were performed in sampling points located on outcrops of various lithological units of the sedimentary sequence (fig. 6). Measurements were performed in three month periods from October 2004 to September 2005. Regional mean atmospheric radon activity changes from $32 \mathrm{~Bq} / \mathrm{m}^{3}$ in winter to $98 \mathrm{~Bq} / \mathrm{m}^{3}$ in summer period (table III) resulting in an average annual value of $72 \mathrm{~Bq} / \mathrm{m}^{3}$.
Low values measured in winter are connected with the freezing of the ground and the existence of snow cover.

In every season value measured at the tailing was distinctly higher than the regional mean (fig. 7).

\section{Conclusions}

Atmospheric radon activity measured in the Sudetes area varies in the broad range due to existence of poorly ventilated valleys in intensive mining areas. On the outcrops of the Karkonosze Granite local anomalies reaching $70 \mathrm{~Bq} / \mathrm{m}^{3}$ were found, but regional mean values are of order 10 $\mathrm{Bq} / \mathrm{m}^{3}$. In the Kowary area of uranium mining atmospheric radon activity of more than 4000 $\mathrm{Bq} / \mathrm{m}^{3}$ can be observed at the entrance to an abandoned gallery. This anomaly can be traced down at a distance of $1 \mathrm{~km}$. The highest regional mean of atmospheric radon activity $\left(72 \mathrm{~Bq} / \mathrm{m}^{3}\right)$ was found in the Nowa Ruda area. Seasonal observations in this area confirmed the existence of anomalies connected with coal mine tailings.

\section{Acknowledgements}

This work was funded by the grant 2022/W/ /ING/05/36.

\section{REFERENCES}

Banaś, M., W. Mielniczuk and A. Piestrzyński (1976): The secondary haloes of uranium dissemination round mine dumps, Nukleonika, 21 (5), 639-645.

GESSEL, T.E. (1983): Background atmospheric $\mathrm{Rn}^{222}$ concentrations outdoors and indoors: a review, Health. Phys., 45, 289-302.

JAGiElaK, J., M. BiernaCKa, J. HenschKe, A. SosińsKa, M. 
BARANOWSKI and R. JANKOWSKI (1992): Radiologiczny Atlas, Polski CELOR Państwowa Agencja Atomistyki, Warszawa.

JELIŃSKI, A. (1965): Geochemia uranu w granitowym masywie Karkonoszy z uwzględnieniem innych masywów granitowych Dolnego Ślasska, IG. Biul., 193, 5-110.

KHAN, H.A. and A.A. QUERESHI (1994): Solid state nuclear track detection: a useful geological/geophysical tool, Nucl. Geophys., 8 (1-37).

MierzeJEwski, M.P. (1993): Przemieszczenia fragmentów litosfery a powstawanie i ruchy magm-wybrane przyklady z regionu sudeckiego i przedsueckiego, Geol. Sudetica, 27, 97-180.

MurAs, K. and J. OLsZEwSKi (1993): Określenie wielkości naturalnego promieniowania jonizujące $\mathrm{w}$ otoczeniu kopalń rud miedzi w Polsce, Medycyna Pracy, XLIV (4), 333-348.

OCHMAnN, A.A. (2003): Distribution of radon activity in the atmosphere above Wzgórza Niemczańsko-Strzelińskie (South-West Poland) and its dependence on uranium and thorium content in the underlying rock and indirect ground basement, Ann. Geophysics, 48 (1), 117-127.

Srivastava, D.S., P. Singh, N.P.S. Rana, A.H. Naqvi, A. AZAM, T.V. RAMACHANDRAN and M.C. SUBBA RAMU (1995): Calibration factor for LR-115 type II track detectors for environmental radon measurements, $\mathrm{Nucl}$. Geophys., 9 (5), 487-495.

Whittlestone, S., E. Robinson and S. Ryan (1992): Radon at the Mauna-Loa Observatory - Transport from distant continents, Atmos. Environ. Part A, 26 (2), 251-260. 